Larry Diamond, who also coedit the Journal of Democracy. The Forum's programs benefit from the advice and involvement of a $\mathrm{Re}$ search Council consisting of U.S.based scholars and specialists, including many eminent political scientists.
For further information about the International Forum, contact David G. Timberman or Debra Liang, The International Forum for Democratic Studies, 1101 15th Street, NW, Suite 802, Washington, D.C. 20005, or call (202) 293-0300.

\section{About the Author}

Marc F. Plattner and Larry Diamond, senior fellow at the Hoover Institution, are codirectors of the International Forum for Democratic Studies, National Endowment for Democracy.

\title{
The Other Game or the Rational Choice Approach to Football
}

Editor's Note: This press release was submitted by Ian Shapiro, Department of Political Science, Yale University.

Most people know that on Saturday, November 19, the Yale Bulldogs trounced the Harvard Crimson in Cambridge by a stunning 32-13. Fewer people are aware that on the same day another equally impressive football defeat was handed to Harvard by Yale. Reviving a long defunct tradition, the Faculty of the Yale Political Science Department took on the Harvard Government Department, beating them $26-8$ in a game that raised $\$ 300$ for charity.
Harvard won the toss. One of their veterans, Professor James Alt, immediately commented "There's one for rational choice," referring to the Harvard/Yale rivalry over political science models. [Yale quarterback Donald Green and lineman Ian Shapiro are coauthors of a recent Yale Press book, Pathologies of Rational Choice Theory, critiquing the Harvard approach]. Unfortunately for Alt and his fellow rational choosers, the toss was the last thing that went well for them. Impressive interceptions by Theordore Marmor, Cathy Cohen, and Douglas Rae led to a 12-0 halftime score. Linemen Shapiro, Rae, and Avi Segal effectively harassed the Crimson at the line of scrimmage all day.

In the second half, wide receivers Doug Reed and Marty Gilens sealed the victory with two impressive touchdown receptions from quarterback Green, and the Yale team coasted to victory, despite a Harvard touchdown and impressive two-point conversion from Harvard quarterback Michael Hagen in the closing seconds. Yale MVP Cohen, playing as wide receiver, defensive back, and punt returner, ran rings around the Harvard offense. Several Harvard players were overheard after the game wondering why their rational strategy had not paid off. 